\title{
Characterization of rock material by point load strength index test and direct cut
}

\author{
Feijoo Calle Ernesto Patricio ${ }^{1}$ y Almache Rodríguez Paúl Andrés ${ }^{2}$ \\ 1pfeijoo@uazuay.edu.ec, ${ }^{2}$ paul45rodriguezl@es.uazuay.edu.ec \\ 'ORCID: https://orcid.org/0000-0001-6901-7933, ${ }^{2}$ ORCID: https://orcid.org/0000-0002-6816-6870 \\ Universidad del Azuay \\ Cuenca-Ecuador
}

Recibido (31/01/2021), Aceptado (02/03/2021)

\begin{abstract}
The objective of this work is to establish a relationship between the cutting time in rocks, determining a speed and the point load strength index test, Is (50), to characterize the rock in terms of resistance and avoid sending samples to laboratories. As a first stage, on andesite samples, $5 \times 5 \times 10 \mathrm{~cm}$ test tubes were made. After the elaboration they were subjected to cutting, using an electric floor cutter and the time was evaluated. This cut was made in a transversal way and two parts were obtained, one of them with dimensions $5 \times 5 \times 5 \mathrm{~cm}$, approximately. In a third stage, the point load strength test was carried out in a press built for this purpose. Finally, the cutting speeds were correlated with the point load test values and only when rock samples do not pigeonhole on the proposed relationship, send them to the laboratory.
\end{abstract}

Keywords: Mining fortification, uniaxial compressive strength, rock cutting, point load strength test index.

\section{Caracterización del material rocoso mediante ensayos de resistencia a carga puntual y corte directo}

Resumen: El objetivo de este trabajo es establecer una relación entre el tiempo de corte en rocas,
determinando una velocidad y el índice de carga puntual, Is (50), para caracterizar la roca en términos
de resistencia y prescindir del envío de muestras a laboratorios. Como primera etapa, sobre muestras
de andesita, se elaboraron probetas de 5 x 5 x $10 \mathrm{~cm}$. Luego de la elaboración se las sometió a
corte, mediante una cortadora eléctrica de piso y se evaluó el tiempo. Este corte se realizó de forma
transversal y se obtuvieron dos partes, una de ellas con dimensiones 5 x 5 x $5 \mathrm{~cm}$, aproximadamente.
En una tercera etapa se ejecutaron los exámenes de carga puntual en una prensa construida para el
efecto. Finalmente se correlacionaron las velocidades de corte con los valores de carga puntual y
solamente cuando muestras de roca no encasillen sobre la relación propuesta, enviarlas al laboratorio.

Palabras clave: Fortificación minera, resistencia a la compresión uniaxial, corte en rocas, índice de carga puntual.

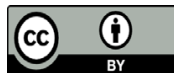




\section{I.INTRODUCTION}

In

In the development of mining structures, such as slopes and tunnels, which are executed for the extraction of mineral resources or materials intended for construction, it's very important to maintain the strategies for the stability of said structures, therefore, to ensure that they remain firm to avoid landslides and/or collapses in all phases of exploitation of the mining project, managing to generate safety for workers and the equipment.

Achieving the stability of the rocky massifs in the exploitation areas is not an easy task, it initially involves obtaining a series of specific data and parameters, some of which are very difficult to calculate in the field and it is necessary to take of samples or controls (test tubes), which must be sent to laboratories for treatment.

These parameters or data range from visualizations and measurements in the rocky massif itself, to obtaining the resistance to simple or uniaxial compression of the rocky material. There is a clear difference between rocky massif and rocky material, the first concept comprises the outcrop including its discontinuities, joints, or joints, while the rocky material is a compact block of the outcrop.

The resistance to simple compression of the rock material or simply of the rock, is a fundamental parameter that must be included within the estimates in the different geomechanical classifications, such as the RMR or Q Index, but its calculation and determination must be carried out in the laboratory, becoming a tedious and expensive activity in the development of the project. An alternative to the determination of the simple compressive strength of the rock is the so-called point load strength index test or Is (50), which provides an estimated value of the load on the rock specimen and it is correlated with the simple compressive strength. The Is (50) test is in situ and inexpensive, which is why it is applied today. Knowing that the rock also presents difficulty in cutting, we try to evaluate its relationship with the Is (50) test.

In this work it is proposed from the theoretical basis used for the effect, the development of the activities that must be fully followed, the methodology to obtain the resistance to simple compression of the rock through the use of the point load strength index test, the cut of the rock, describing a clear and statistical procedure, which can be used in a mining project, generating a strategy to obtain the parameter with an easy-to-use final mathematical relationship, it should be emphasized that in this work the results obtained have generated a very important expectation about your application.

\section{II.DEVELOPMENT}

In this document, we will begin with a description of the concepts and theoretical basis regarding the stability of mining structures, both in open pit and underground. Currently the fundamental problem for Mining Engineers is the need to apply technical tests in situ, but it is essential to know the limitations and properties of the methods in order to establish a solution to the problem.1.

In Rock Mechanics, which is in charge of studying the properties of rocks and rock masses, it is very important to define some of them, which, without diminishing the importance of others, are considered a priority. The behavior of a mass or massif of rock in situ is different from a rocky material, because the rocky material is much stronger and a rock mass usually presents systems of structural weaknesses called joints, fractures, fissures, discontinuities, faults. Of various sizes 2.

For the development of mining activities, the stability and support of galleries or slopes is a fundamental part and is established as one of the most important tasks, since the correct fortification fulfills its objective of avoiding collapse or falling blocks and consequently, guarantees the safety, mainly of personnel, tools or equipment and production, so that in this way, with adequate and technical fortification, it will be possible to avoid work accidents. Therefore, we can generate, for the staff, a safe area and work environment, achieving greater performance and providing security for the company. 3 . This need has led to the development of so-called geomechanical classifications, which use a series of parameters for the evaluation of rock masses.

Nowadays, geomechanical classifications have become widespread and are widely used, both in the design and execution phases, in all types of works in rock massifs. It is therefore important to know the limitations and difficulties that each of the classifications presents. 4 and a fundamental parameter is the resistance to simple compression or point load strength index test, Is (50). However, many times due to the conditions in which the mining works are found, it's complicated and sometimes almost impossible to send rock samples to laboratories to determine the value of the UCS, and in these times, it is the problem of those in charge of evaluating stability. Of the structures in the field, which is why, there is an urgent need to generate alternatives in situ for the assessment 
of the UCS 5. Therefore, the necessary bases for the development of the proposal are specified below.

Rocks are natural aggregates of mineral particles; they combine through a strong permanent cohesion. If its resistance to simple compression (without drainage) is greater than $5 \mathrm{~kg} / \mathrm{cm} 2$, it's generally considered a rock 6 .

The rocks that make up the earth's crust are divided into three categories: igneous rocks, metamorphic rocks, and sedimentary rocks. Igneous rocks are formed by cooling and solidifying agglomerates of hot fluid called magma. The chemical composition of the first $16 \mathrm{Km}$ of the crust clearly shows that some elements such as $\mathrm{Si}, \mathrm{O}, \mathrm{Fe}$ and $\mathrm{Al}$ dominate and account for approximately $87 \%$. Followed by the alkaline earth and alkaline ones: $\mathrm{Ca}, \mathrm{Mg}$, $\mathrm{Na}$ and $\mathrm{K}$. In a small proportion, Ti, $\mathrm{P}, \mathrm{Mn}, \mathrm{S}, \mathrm{Cl}$ and $\mathrm{C} 7$.

The foundations of this work begin with obtaining samples of the rock studied comes from an outcrop located in the province of Cañar (Ecuador), in the sector called Cojitambo, an outcrop composed of a travertine and a volcanic formation of the andesite type 8. Andesites are fine-grained volcanic rocks, they are common, as lava flows in orogenic regions and occasionally form small intrusions. They are compact, sometimes vesicular and commonly brown in color, and in total extent, they rank second after basalt. Many andesite flows are found in continental areas in the Andes of South America (from which they take their name) where many volcanoes have emitted ash and lava of andesitic composition 9. If this is the case, the phenocrysts are generally transparent rectangular plagioclase crystals or elongated black amphibole crystals. Andesite contains small amounts of quartz, while rhyolite consists of approximately 25 percent quartz 10 .

\section{A.Rock cutting}

Rock cutting is an activity in which the skill and experience of the operator predominates, however, having the appropriate machinery it can be developed without inconvenience by a worker.

One of the properties to consider when cutting rocks is the versatility of the cutting machine, particularly with regard to the possibility of varying the performance and peripheral speed of the blade during the cutting process. 11. We should consider that cutting a material requires the power consumption of the saw, so that for hard materials and high cutting conditions, the cutting speed or the cutting rate is required as the cut rock surface. In these cases, if we are keeping the cutting rate, the peripheral speed of the blade can increase, reducing energy consumption.

Initial considerations should be taken into account when choosing cutting equipment, it's done based on detecting the following intrinsic aspects of the rock such as abrasiveness, compressive strength, toughness, hardness, porosity, etc. It is also necessary to take into account the rate of production and the degree of mechanization of the tasks to be done. 2 .

The Covington's disc cutting machine consists of a tile saw and is a high-performance floor model for cutting glass and stone. This is a plunge saw, meaning the cutting fluid is deposited into the tank and the rotating saw blade lifts the cutting fluid up and around the part. Covington lines the saw tank, hood, and chassis for durability and longevity. The hood fits exactly into the tank and prevents leaks. The hood can be opened with a sturdy steel arm for easy loading and unloading of parts13.

\section{B.Unconfined Compressive Strength}

The unconfined compressive strength of rocks is the most common measure to define the reasons for failure and the geomechanical procedure of a given rock mass. To obtain it in the laboratory examinations, it requires scrupulously prepared samples and a certain considerable time to be able to know the result, which can present a high cost. Anisotropic rocks in particular are difficult to perform tests due to their variant resistance, so numerous laboratory tests are necessary to obtain representative parameters of the entire resistance range 14 . The resistance of a rock is the result of the stress that it undergoes when it breaks. When the resistance is calculated in unconfined rock specimens, it is designated simple compression resistance and its value is used for the geotechnical classification of rocks. To obtain this property, the simple compression test is used.

The purpose of this test is to measure the compressive strength of a rock specimen, subjected to an axial load. To carry out the test, it is necessary to have a press of adequate capacity that allows to use the load on the specimen at a constant speed until it breaks in a time interval between 5 and 15 minutes, also the loading speed can be set between intervals of 0.5 to $1 \mathrm{MPa} / \mathrm{s} 15$. The specimen is placed between the discs of the press, well centered. Where a settlement load equivalent to $1 \%$ of the estimated simple compressive strength is applied. At this time, the charge indicator clock is reset. The speed of application of the load is fixed, beginning the compression, until the sample breaks. 
Equation (1) shows us how to determine the simple compressive strength of a specimen:

$$
U C S=\sigma_{c}=\frac{P}{A}
$$

Where:

$\mathrm{P}=$ is the maximum load to which the specimen has been subjected during the test.

$\mathrm{A}=$ is the cross-sectional area of the specimen.

\section{C.The Point Load Strength Index Test}

The point load strength index test is one of the most important tests used for the indirect determination of UCS, since in the implementation of the press it can be used in situ or in a laboratory, in addition to that requires little or no sample preparation for testing 16. The point load or break test between points is a basic test that can be carried out in the field with cores without modification or with rock fragments. This is based on applying a point load to a piece of rock until it breaks, obtaining an Is index that is correlated with the simple compressive strength of the rock. 17. The point load strength index test value can be used as an indirect estimate of the uniaxial or simple compression of the rock, the sample that is carried out may be a rock core, a block or an irregular rock lump 18.

The point load test consists of breaking a piece of rock between two conical points of hardened steel. The samples that will later be placed between said tips can be of any shape, but it is recommended that their diameter is not less than $50 \mathrm{~mm}$, since the volume of said test piece influences its resistance.

Equation 2 allows us to calculate the point load index without correction:

$$
I_{S}=\frac{P}{(D e)^{2}}
$$

Where:

$\mathrm{P}=$ applied load in $\mathrm{N}$.

$\mathrm{De}=$ equivalent core diameter in $\mathrm{mm} 19$.

The distances of the fragments are taken which must obey with the provisions indicated in the standard. The ratio $0.3<\mathrm{D} / \mathrm{W}<1$ is preferably close to 1 . The distance $\mathrm{L}>0.5 \mathrm{~W}$ ( $\mathrm{L}$ distance from the end of the rock to the conical points) and the $\mathrm{W}$.

Equation 3 determines the equivalent diameter De as a function of the dimensions of the irregular fragments:

$$
(D e)^{2}=\frac{4 A}{\pi}
$$

Where:

$$
\mathrm{A}=\mathrm{WD}
$$

Where $\mathrm{A}$ is the minimum cross-sectional area parallel to the direction of the load in $\mathrm{mm}^{2}$.

The corrected point load strength index test, Is (50) of a rock sample is defined as the value of Is that has been measured by a diametral test with $\mathrm{D}=50 \mathrm{~mm}$. When a rock classification is essential, the most reliable method to achieve Is (50) is to carry out the tests with diameters of $\mathrm{D}=50 \mathrm{~mm}$ or very close to this value. Most point load tests are carried out using sample sizes other than the mentioned diameter 20.

In equation 5 we can obtain the size correction: 


$$
I s(50)=\left(\frac{D e}{50}\right)^{0.45} \cdot I s
$$

Finally, in equation 6 we can observe the relationship between the resistance to simple compression of the rock specimen, related to the point load index 21.

$$
I_{S}=\frac{\sigma_{c}}{14+0.175 D}
$$

\section{III.METHODOLOGY}

At this point, it will be presented to you a detailed explanation of the operations carried out to achieve the objectives established in this work. We will start with a description of the number of samples with their respective preparation, their cutting process, the execution of the point load strength index test and the determination of the simple compressive strength.

Initially, 60 samples were taken from the study area, which is located in the sector called Cojitambo, in the province of Cañar (Ecuador), this can be seen in the figure 1 .

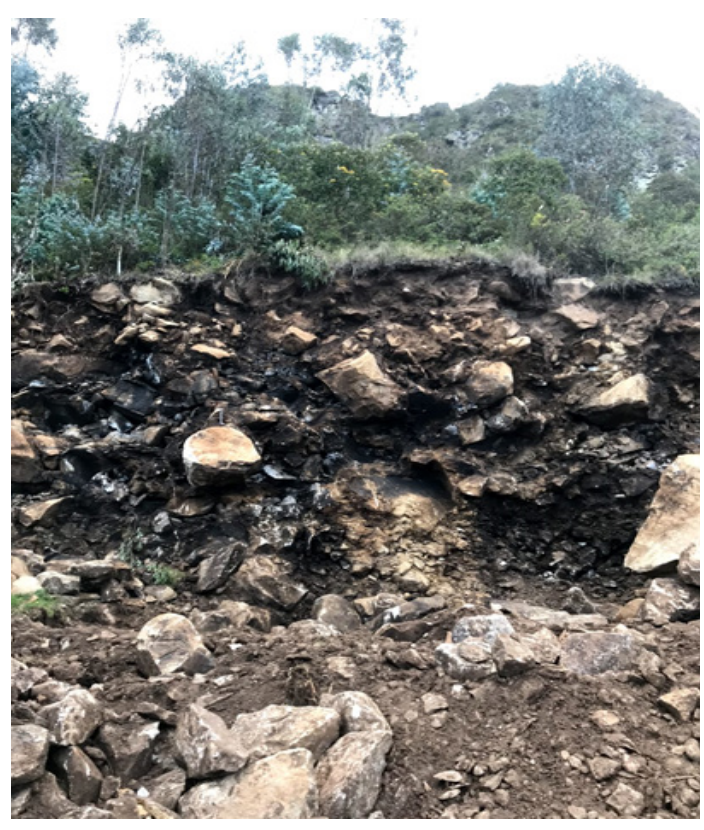

Fig. 1. Cojitambo

Subsequently, cuttings were carried out on each of the samples to obtain specimens of approximately $5 \times 5 \times 10 \mathrm{~cm}$. Once the specimens are created, it is verified that they do not have cracks and that the dimensions are very close to those mentioned above. A specimen ready for cutting can be seen in figure 2, and another specimen after cutting in figure 3 . 


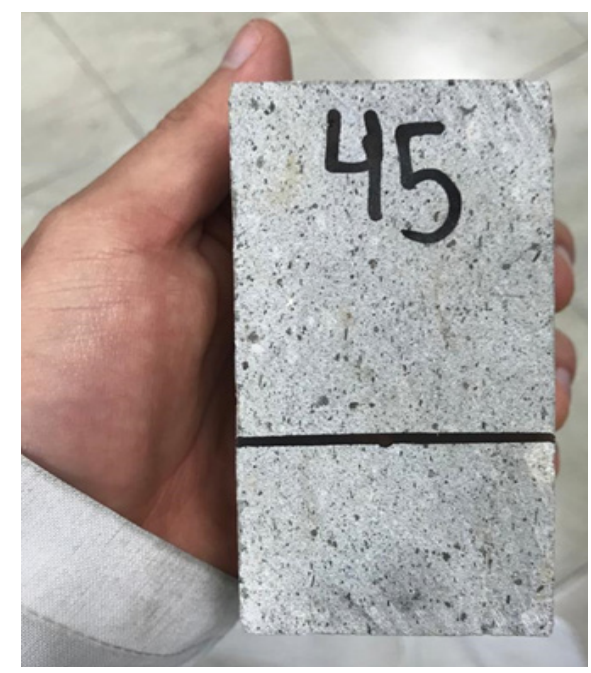

Fig. 2. Rock specimen ready for cutting

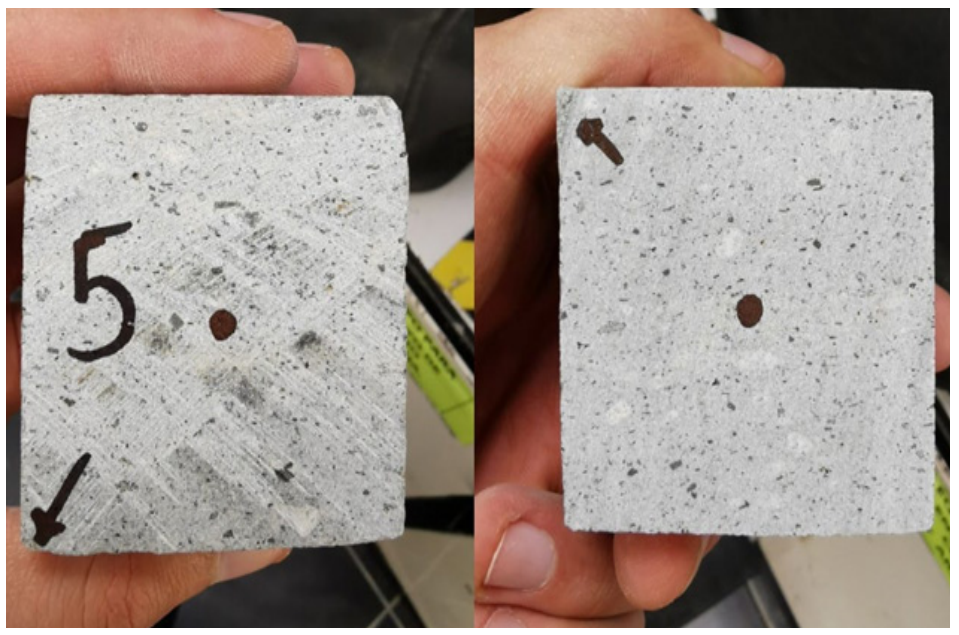

Fig. 3. Rock specimen after cutting

Before starting the cutting process, the distances that exist between the jaw and the disk must be measured in conjunction with the specimen and draw a line on the specimen to be able to make the appropriate cut that is needed, as shown in the figure 2 .

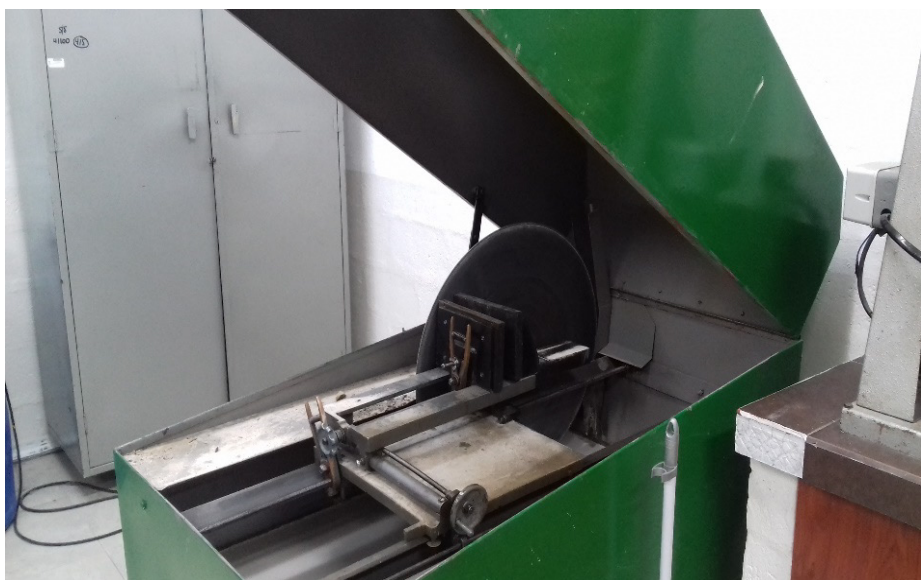

Fig. 4. Covington Floor Saw 
It's necessary to emphasize that the cutter used was a floor Covington and it was worked with a $30 \mathrm{~cm}$ disc radius and with 78.14 liters of water-oil. The fluid must always be in a 10: 1 ratio. The cutter can be seen in figure 4 .

The selected specimen passes to the cutting process in which the time of its execution carried out by the disc cutter is taken, resulting in two specimens of different dimensions, the first with measurements of approximately $5 \times 5 \times 5 \mathrm{~cm}$ that will later be used to execute the point load rupture and the second specimen with approximate dimensions $5 \times 5 \times 4.3 \mathrm{~cm}$ will be used for the rupture in simple compression. It is important at this point to establish that the cutting time is evaluated in each specimen with the premise that, if the specimen presents greater resistance, the cutting time will be longer or if the specimen is less hard, the time will be shorter, this due to the anisotropy of the rocks. It is also necessary to clarify that the dimensions of the initial $5 \times 5 \times 10 \mathrm{~cm}$ specimens are established so that when cutting, two elements are produced that obtain the dimensions and relationships necessary by the standard, both for the point load index test, and for determination of compressive strength.

Once the described specimens are obtained, the point loading process begins, in a press built for this purpose, the press can be seen in figure 5 .

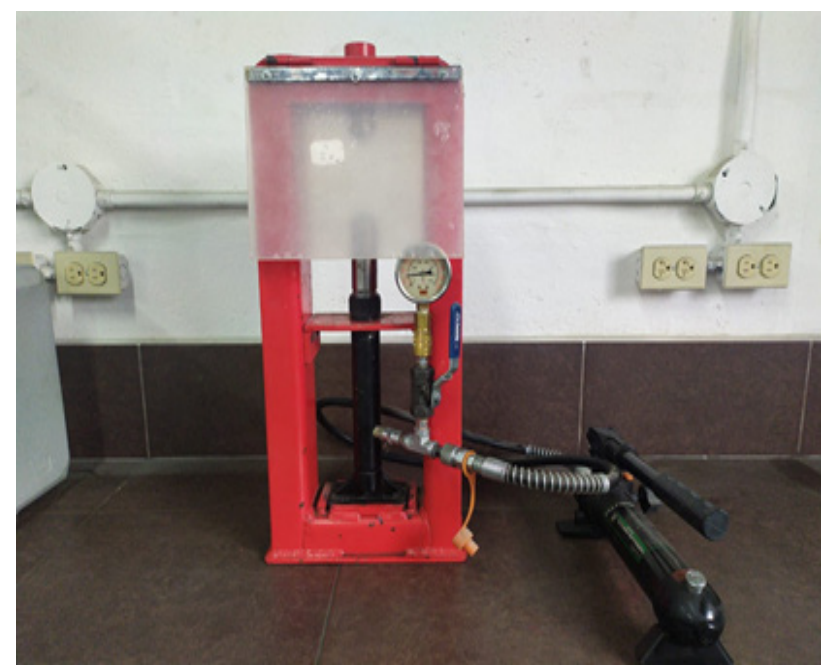

Fig. 5. Point load strength index test Press

As a final step, the specimens for compressive strength are taken and subjected to the respective test, the Humboldt machine used for this test can be seen in Figure 6.

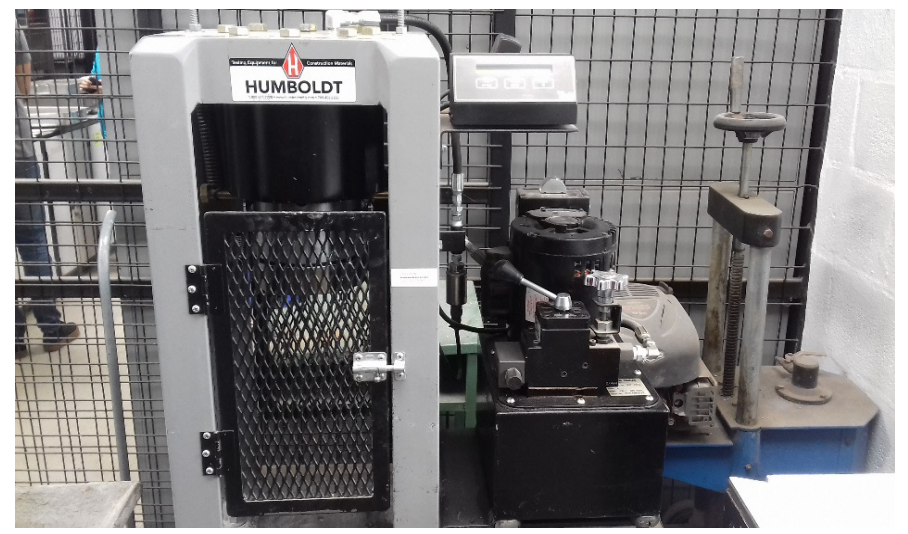

Fig. 6. Humboldt resistance press

\section{IV.RESULTS}

After executing all the tests, it has been possible to obtain a series of data which in their treatment will represent different relationships between the parameters obtained. Initially, Table 1 is shown, in which the results of cutting time and cutting speed are presented. 
Table 1. Results of the cutting speed.

\begin{tabular}{|c|c|c|c|c|c|c|c|}
\hline $\begin{array}{c}\text { Test } \\
\text { tube }\end{array}$ & $\begin{array}{c}\text { speed } \\
(\mathbf{m m} / \mathbf{m i} \\
\mathbf{n})\end{array}$ & $\begin{array}{c}\text { Test } \\
\text { tube }\end{array}$ & $\begin{array}{c}\mathbf{s p e e d} \\
(\mathbf{m m} / \mathbf{m i} \\
\mathbf{n})\end{array}$ & $\begin{array}{c}\text { Test } \\
\text { tube }\end{array}$ & $\begin{array}{c}\mathbf{s p e e d} \\
(\mathbf{m m} / \mathbf{m i} \\
\mathbf{n})\end{array}$ & $\begin{array}{c}\text { Test } \\
\text { tube }\end{array}$ & $\begin{array}{c}\text { speed } \\
(\mathbf{m m} / \mathbf{m i} \\
\mathbf{n})\end{array}$ \\
\hline $\mathbf{1}$ & 1.951 & $\mathbf{1 6}$ & 2.056 & $\mathbf{3 1}$ & 2.087 & $\mathbf{4 6}$ & 2.121 \\
\hline $\mathbf{2}$ & 1.978 & $\mathbf{1 7}$ & 2.057 & $\mathbf{3 2}$ & 2.087 & $\mathbf{4 7}$ & 2.130 \\
\hline $\mathbf{3}$ & 1.986 & $\mathbf{1 8}$ & 2.058 & $\mathbf{3 3}$ & 2.091 & $\mathbf{4 8}$ & 2.131 \\
\hline $\mathbf{4}$ & 2.011 & $\mathbf{1 9}$ & 2.058 & $\mathbf{3 4}$ & 2.091 & $\mathbf{4 9}$ & 2.133 \\
\hline $\mathbf{5}$ & 2.016 & $\mathbf{2 0}$ & 2.060 & $\mathbf{3 5}$ & 2.092 & $\mathbf{5 0}$ & 2.141 \\
\hline $\mathbf{6}$ & 2.017 & $\mathbf{2 1}$ & 2.064 & $\mathbf{3 6}$ & 2.098 & $\mathbf{5 1}$ & 2.142 \\
\hline $\mathbf{7}$ & 2.018 & $\mathbf{2 2}$ & 2.064 & $\mathbf{3 7}$ & 2.101 & $\mathbf{5 2}$ & 2.145 \\
\hline $\mathbf{8}$ & 2.030 & $\mathbf{2 3}$ & 2.065 & $\mathbf{3 8}$ & 2.105 & $\mathbf{5 3}$ & 2.150 \\
\hline $\mathbf{9}$ & 2.035 & $\mathbf{2 4}$ & 2.065 & $\mathbf{3 9}$ & 2.106 & $\mathbf{5 4}$ & 2.151 \\
\hline $\mathbf{1 0}$ & 2.038 & $\mathbf{2 5}$ & 2.069 & $\mathbf{4 0}$ & 2.108 & $\mathbf{5 5}$ & 2.164 \\
\hline $\mathbf{1 1}$ & 2.039 & $\mathbf{2 6}$ & 2.070 & $\mathbf{4 1}$ & 2.109 & $\mathbf{5 6}$ & 2.173 \\
\hline $\mathbf{1 2}$ & 2.040 & $\mathbf{2 7}$ & 2.072 & $\mathbf{4 2}$ & 2.116 & $\mathbf{5 7}$ & 2.178 \\
\hline $\mathbf{1 3}$ & 2.045 & $\mathbf{2 8}$ & 2.078 & $\mathbf{4 3}$ & 2.117 & $\mathbf{5 8}$ & 2.184 \\
\hline $\mathbf{1 4}$ & 2.051 & $\mathbf{2 9}$ & 2.082 & $\mathbf{4 4}$ & 2.118 & $\mathbf{5 9}$ & 2.185 \\
\hline $\mathbf{1 5}$ & 2.055 & $\mathbf{3 0}$ & 2.084 & $\mathbf{4 5}$ & 2.120 & $\mathbf{6 0}$ & 2.193 \\
\hline
\end{tabular}

Table 2. Results of the point load strength index test by test in a conical point press

\begin{tabular}{|c|c|c|c|c|c|c|c|}
\hline $\begin{array}{c}\text { Test } \\
\text { tube }\end{array}$ & Is (MPa) & $\begin{array}{c}\text { Test } \\
\text { tube }\end{array}$ & Is (MPa) & $\begin{array}{c}\text { Test } \\
\text { tube }\end{array}$ & Is (MPa) & $\begin{array}{c}\text { Test } \\
\text { tube }\end{array}$ & Is (MPa) \\
\hline $\mathbf{1}$ & 2.412 & $\mathbf{1 6}$ & 2.926 & $\mathbf{3 1}$ & 3.069 & $\mathbf{4 6}$ & 3.183 \\
\hline $\mathbf{2}$ & 2.451 & $\mathbf{1 7}$ & 2.938 & $\mathbf{3 2}$ & 3.069 & $\mathbf{4 7}$ & 3.196 \\
\hline $\mathbf{3}$ & 2.474 & $\mathbf{1 8}$ & 2.939 & $\mathbf{3 3}$ & 3.099 & $\mathbf{4 8}$ & 3.213 \\
\hline $\mathbf{4}$ & 2.699 & $\mathbf{1 9}$ & 2.939 & $\mathbf{3 4}$ & 3.101 & $\mathbf{4 9}$ & 3.216 \\
\hline $\mathbf{5}$ & 2.756 & $\mathbf{2 0}$ & 2.939 & $\mathbf{3 5}$ & 3.101 & $\mathbf{5 0}$ & 3.216 \\
\hline $\mathbf{6}$ & 2.756 & $\mathbf{2 1}$ & 2.955 & $\mathbf{3 6}$ & 3.115 & $\mathbf{5 1}$ & 3.261 \\
\hline $\mathbf{7}$ & 2.816 & $\mathbf{2 2}$ & 2.972 & $\mathbf{3 7}$ & 3.119 & $\mathbf{5 2}$ & 3.279 \\
\hline $\mathbf{8}$ & 2.842 & $\mathbf{2 3}$ & 2.986 & $\mathbf{3 8}$ & 3.131 & $\mathbf{5 3}$ & 3.315 \\
\hline $\mathbf{9}$ & 2.842 & $\mathbf{2 4}$ & 3.005 & $\mathbf{3 9}$ & 3.165 & $\mathbf{5 4}$ & 3.324 \\
\hline $\mathbf{1 0}$ & 2.842 & $\mathbf{2 5}$ & 3.035 & $\mathbf{4 0}$ & 3.165 & $\mathbf{5 5}$ & 3.329 \\
\hline $\mathbf{1 1}$ & 2.881 & $\mathbf{2 6}$ & 3.036 & $\mathbf{4 1}$ & 3.181 & $\mathbf{5 6}$ & 3.330 \\
\hline $\mathbf{1 2}$ & 2.894 & $\mathbf{2 7}$ & 3.036 & $\mathbf{4 2}$ & 3.183 & $\mathbf{5 7}$ & 3.410 \\
\hline $\mathbf{1 3}$ & 2.896 & $\mathbf{2 8}$ & 3.052 & $\mathbf{4 3}$ & 3.183 & $\mathbf{5 8}$ & 3.450 \\
\hline $\mathbf{1 4}$ & 2.908 & $\mathbf{2 9}$ & 3.052 & $\mathbf{4 4}$ & 3.183 & $\mathbf{5 9}$ & 3.524 \\
\hline $\mathbf{1 5}$ & 2.910 & $\mathbf{3 0}$ & 3.069 & $\mathbf{4 5}$ & 3.183 & $\mathbf{6 0}$ & 3.635 \\
\hline
\end{tabular}

Finally, in table 3 we can see the results of the compressive strength tests of the specimens.

Table 3. Results of the point load strength index test by test in the Humboldt press

\begin{tabular}{|c|c|c|c|c|c|c|c|}
\hline $\begin{array}{c}\text { Test } \\
\text { tube }\end{array}$ & Is (MPa) & $\begin{array}{c}\text { Test } \\
\text { tube }\end{array}$ & Is (MPa) & $\begin{array}{c}\text { Test } \\
\text { tube }\end{array}$ & Is (MPa) & $\begin{array}{c}\text { Test } \\
\text { tube }\end{array}$ & Is (MPa) \\
\hline $\mathbf{1}$ & 1.106 & $\mathbf{1 6}$ & 1.441 & $\mathbf{3 1}$ & 1.640 & $\mathbf{4 6}$ & 1.855 \\
\hline $\mathbf{2}$ & 1.136 & $\mathbf{1 7}$ & 1.458 & $\mathbf{3 2}$ & 1.653 & $\mathbf{4 7}$ & 1.874 \\
\hline $\mathbf{3}$ & 1.181 & $\mathbf{1 8}$ & 1.475 & $\mathbf{3 3}$ & 1.658 & $\mathbf{4 8}$ & 1.894 \\
\hline $\mathbf{4}$ & 1.210 & $\mathbf{1 9}$ & 1.489 & $\mathbf{3 4}$ & 1.664 & $\mathbf{4 9}$ & 1.905 \\
\hline $\mathbf{5}$ & 1.217 & $\mathbf{2 0}$ & 1.493 & $\mathbf{3 5}$ & 1.669 & $\mathbf{5 0}$ & 1.916 \\
\hline $\mathbf{6}$ & 1.261 & $\mathbf{2 1}$ & 1.523 & $\mathbf{3 6}$ & 1.711 & $\mathbf{5 1}$ & 1.931 \\
\hline $\mathbf{7}$ & 1.355 & $\mathbf{2 2}$ & 1.542 & $\mathbf{3 7}$ & 1.729 & $\mathbf{5 2}$ & 1.972 \\
\hline $\mathbf{8}$ & 1.368 & $\mathbf{2 3}$ & 1.605 & $\mathbf{3 8}$ & 1.762 & $\mathbf{5 3}$ & 1.973 \\
\hline $\mathbf{9}$ & 1.380 & $\mathbf{2 4}$ & 1.609 & $\mathbf{3 9}$ & 1.762 & $\mathbf{5 4}$ & 1.992 \\
\hline $\mathbf{1 0}$ & 1.385 & $\mathbf{2 5}$ & 1.614 & $\mathbf{4 0}$ & 1.776 & $\mathbf{5 5}$ & 2.126 \\
\hline $\mathbf{1 1}$ & 1.409 & $\mathbf{2 6}$ & 1.619 & $\mathbf{4 1}$ & 1.784 & $\mathbf{5 6}$ & 2.183 \\
\hline $\mathbf{1 2}$ & 1.410 & $\mathbf{2 7}$ & 1.624 & $\mathbf{4 2}$ & 1.787 & $\mathbf{5 7}$ & 2.209 \\
\hline $\mathbf{1 3}$ & 1.413 & $\mathbf{2 8}$ & 1.629 & $\mathbf{4 3}$ & 1.807 & $\mathbf{5 8}$ & 2.250 \\
\hline $\mathbf{1 4}$ & 1.427 & $\mathbf{2 9}$ & 1.634 & $\mathbf{4 4}$ & 1.821 & $\mathbf{5 9}$ & 2.338 \\
\hline $\mathbf{1 5}$ & 1.435 & $\mathbf{3 0}$ & 1.637 & $\mathbf{4 5}$ & 1.840 & $\mathbf{6 0}$ & 2.377 \\
\hline
\end{tabular}


After analyzing the data, by a reasoning effect, it can be stated that the cutting time is greater when the rock resistance is greater, consequently, the cutting speed the lower it is, and the compressive strength of the specimen is greater.

This statement leads us to generate, both for the point load strength index test in the conical tip press, and for the point load index due to the resistance to simple compression, the following graphs (Figures 7 and 8).

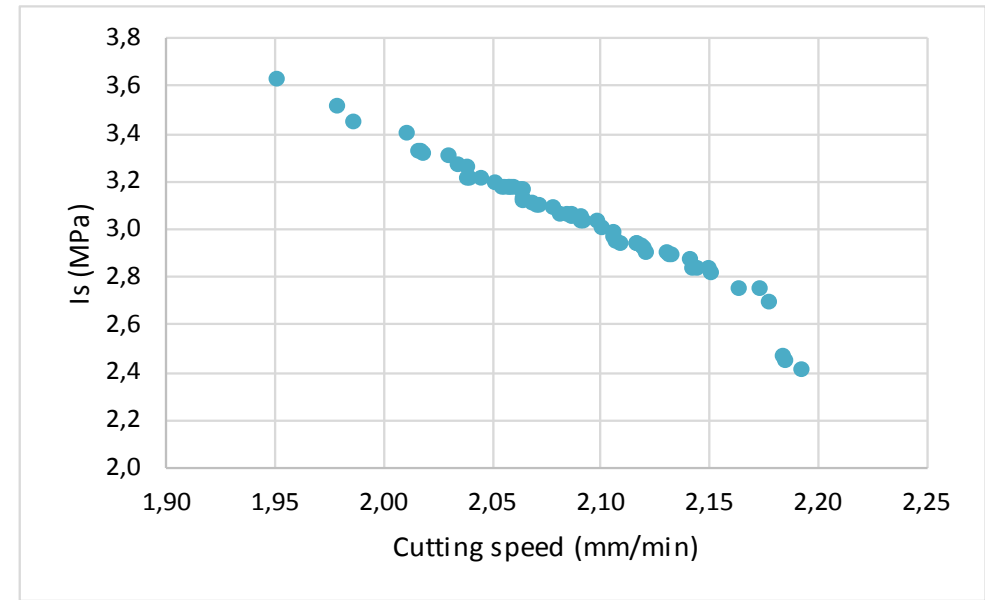

Fig. 7. Results of the Point load index in conical tips vs. Cutting speed

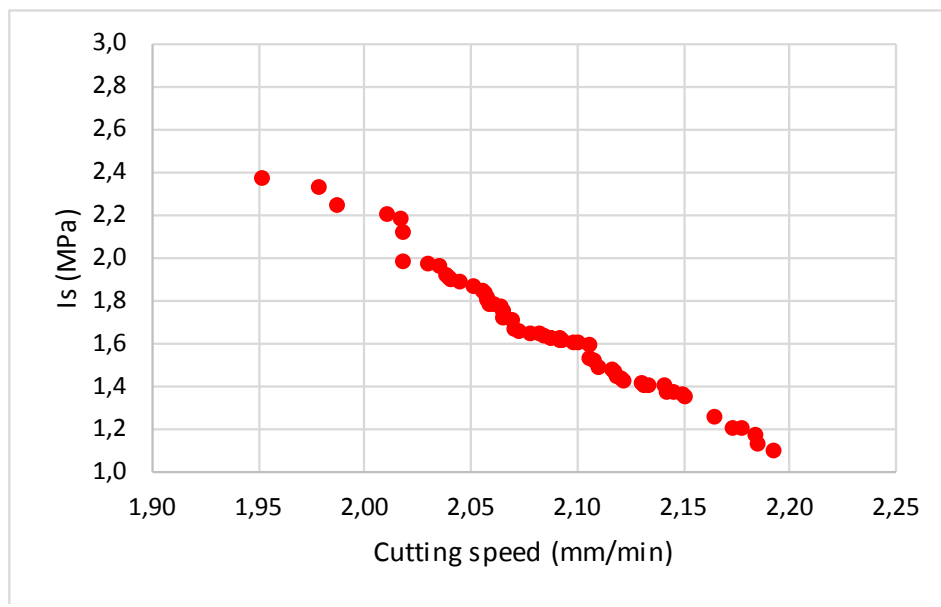

Fig. 8. Humboldt Press Point Load Index Results Graph vs. Cutting speed

Having seen the graphics and adding the respective trend lines, which have the highest R2, the following equations are proposed, (7) for the point load index obtained in the conical point press and (8) for the point load index obtained from the Humboldt press:

$$
\begin{gathered}
I_{S}=-4.3544 \cdot V c+12.138 \\
R^{2}=0.9603 \\
I_{S}=-5.4836 \cdot V c+13.107 \\
R^{2}=0.9789
\end{gathered}
$$

By observing the equations, we can indicate that in practical terms they both have the same slope and we can execute a final correction. For a better observation of the graphs, Figure 9 is presented. 


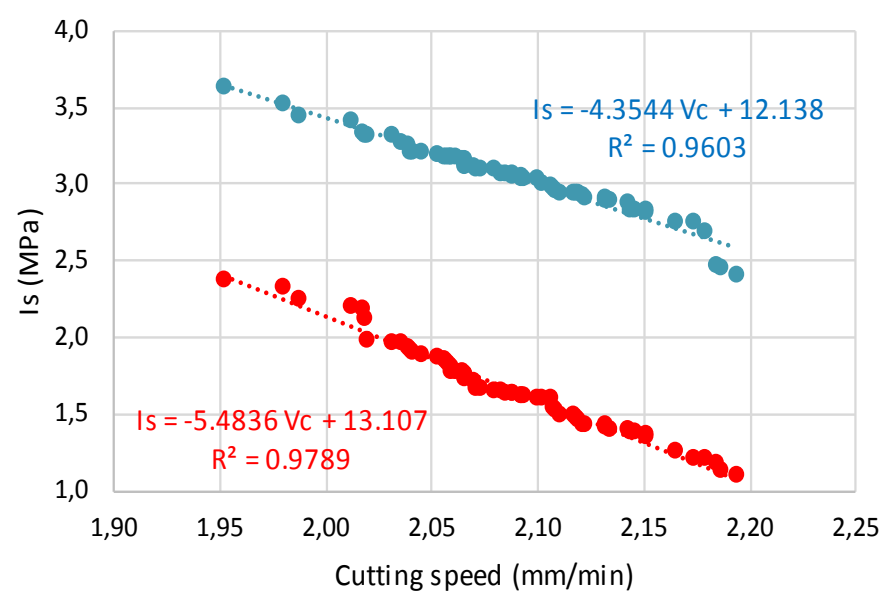

Fig. 9. Equations and trend lines of processes

If a speed, for this same type of rocky material, is $2 \mathrm{~mm} / \mathrm{min}$, the point load strength index test generates a value of $3.4292 \mathrm{MPa}$, while, with the equation for simple compressive strength, the point load strength index test it is $2.1398 \mathrm{MPa}$, which we must correct towards the final value. When comparing the equations, we can state that between the two there is an error that could be reduced considerably if the equation is proposed:

$$
I_{S}=-4.919 \cdot V c+11.838
$$

Which has been obtained with the mean of the slopes and subtracting 0.3 from the intercept value of the line. With equation (9) it is determined that the error is approximately $6.5 \%$, which for classification purposes of the rock type is quite acceptable.

\section{V.CONCLUSIONS}

With this research, an alternative is proposed to obtain the resistance to simple compression of rocks, through the point load index, in mining operations, in order to solve the problem of sending samples to the laboratory, generating savings in time and money.

The correlations obtained between the cutting speed and the point load index, Is (50), as well as with the resistance to simple compression, are acceptable due to the fact that they present an R2 with values between 0.9 to 1 .

Since the study was carried out in the Cojitambo area and there are optimal results of the resistance of the andesite rock, the use of this research for the exploitation of said material is very favorable, since said rock is used for driveways, paths, curbs, decorative coatings for homes, buildings and roads, because their point load index ranges from 1.1 to $2.4 \mathrm{MPa}$.

The equipment used in this research is appropriate and suitable for each of the processes carried out, for this reason optimal results have been achieved that have guaranteed our alternative as an excellent option to find the point load strength index test, Is (50), for the aforementioned are feasible for such equipment to be acquired in a mining camp.

With this research and the proposed methodology, it can be generalized and carried out in a mining project, with reliable results, but because it is perfectible, more case studies can be generated, modifying the different variables present in the study.

\section{REFERENCES}

[1]P. Feijoo, R. Aucay, D. Ordoñez, "Aplicación del esclerómetro para la determinación de resistencia a compresión de rocas", presentado en el IV Congreso Internacional de Minería y Metalúrgia (MINEMETAL), Varadero, 
Cuba, 2018.

[2]P. Feijoo y M. Román, «Correlación entre la Deformación y la Resistencia a la Compresión de rocas», uct, vol. 23, n. ${ }^{\circ} 91$, p. 6, may. 2019.

[3]P. Feijoo, A. Bravo, N. Escandón, "Aplicación "UDAFORMIN" para la determinación del tipo de fortificación minera", presentado en el XII Congreso Iberoamericano de Computación para el Desarrollo (COMPDES), San Salvador, El Salvador, 2019.

[4]P. Feijoo y C. Iñiguez, «Corte en las Rocas y su Relación con la Resistencia a Comprensión Simple», RISTI, n. ${ }^{\circ}$ E 30, p. 59-67, jun. 2020.

[5]P. Feijoo y J. Padrón, «La Resistividad de Rocas y su Relación con la Resistencia a Comprensión Simple en Mina», UCT, vol. 24, n. ${ }^{\circ}$ 99, pp. 61-67, abr. 2020.

[6]M. González. El terreno. Ediciones UPC. Barcelona. España, 2001.

[7]E. Besoain. Mineralogía de Suelos. Turrialba: Instituto Interamericano de Ciencias Agrícolas de la OEA, 1970.

[8]P. Feijoo, A. Flores, B. Feijoo, "The Concept of the Granulometric Area and Its Relation with the Resistance to the Simple Compression of Rocks", presentado en la 7th International Engineering, Sciences and Technology Conference (IESTEC), Panamá, Panamá, 2019, pp. 52-56, doi: 10.1109/IESTEC46403.2019.00018

[9]F. Blyth. Geología para Ingenieros. Cecsa. México D. F. México, 2003.

[10] E. Tarbuck \& F. Lutgens. Ciencias de la Tierra: Una introducción a la Geología Física. Pearson. Madrid. España, 2005.

[11]L. Suarez del Rio, A. Rodríguez, L. Calleja, V. Ruiz de Argandoña, «El corte de rocas ornamentales con discos diamantados: influencia de los factores propios del sistema de corte», CSIC, vol. 48, n. ${ }^{\circ}$ 250, pp. 53-59, abr-mayjun 1998.

[12]Universidad Politécnica de Madrid. Explotaciones de Roca Ornamental. Diseño de explotaciones y selección de maquinaria y equipos. UPM. Madrid. España, 2007.

[13]Catalog, Covington, (2019). LAPIDARY \& GLASS MACHINERY, USA. Retrieved from https://covington-engineering.com/content/pdf/Covington-Catalog.pdf

[14]D. Burbano, T. García, «Estimación empírica de la resistencia a compresión simple a partir del ensayo de carga puntual en rocas anisótropas (esquistos y pizarras)», FIGEMPA, vol.1, n. ${ }^{\circ}$ 2, pp. 13-16, dic. 2016.

[15]P. Ramírez, L. de la Cuadra, R. Lain, E. Grigalbo. Mecánica de rocas aplicada a la minería metálica subterránea. Instituto Geológico Minero. Madrid. España, 1984.

[16]P. Cordero, "Manual de prácticas de laboratorio de Mecánica de Rocas (Parte I)" tesis, Universidad Nacional Autónoma de México, México D.F., México, 2019.

[17]L. González de Vallejo, M. Ferrer. Manual de campo para la descripción y caracterización de macizos rocosos en afloramientos. Instituto Geológico y Minero de España. Madrid. España, 2007.

[18]P. Pohjanpera, T. Wanne, E., Johansson. Point Load Test Results From Olkiluoto Area Borehole Cores. Posiva. Finlandia, 2005.

[19]P. Ramírez, L. Alejano. Mecánica de rocas: fundamentos e ingeniería de taludes. Universidad Politécnica de Madrid. Madrid. España, 2004.

[20]M. Navarrete, W. Martínez, E. Alonso, C. Lara, A. Bedolla, H. Chávez, D. Delgado, J. Arteaga. «Caracterización de propiedades físico-mecánicas de rocas ígneas utilizadas en obras de infraestructura», ALCONPANT, vol. 3, n. ${ }^{\circ}$ 2, pp. 133-143, ago. 2013.

[21]P. Feijoo, "Manual de mecánica de rocas y estabilidad de túneles y taludes" tesis, Universidad del Azuay, Cuenca, Ecuador, 1997. 


\section{RESUMEN CURRICULAR}

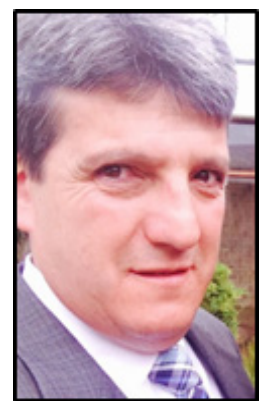

Patricio Feijoo, Mining Engineer, graduated fro $m$ the University of A zuay (Cuenca-Ecuador), with studies and internships in: Bolivia, Brazil, Spain, Australia in areas of geology, geophysics and development of mining activities. He is linked to teaching at the University of Azuay.

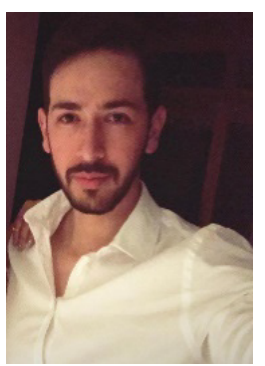

Paúl Almache, Mining Engineer, graduated from the University of A zuay in 2021 (CuencaEcuador), with internships in: The asphalt plant of the Municipality of Cuenca and in the Ministry of energy and non-renewable resources zonal 6. 